\title{
Disaster education in Turkey: Trends in theses and articles between 2003 and 2020
}

\author{
Ufuk Sözcü \\ Kastamonu Science High School, Ministry of Education, Turkey
}

\begin{abstract}
Many disastrous events have taken place in Turkey, most of which have been of natural origin. When the loss of life and property caused by these disasters is analyzed, the increasein recent years is striking. "Disaster education", given in order to prevent and the negative consequences of such disasters, is of great importance. Within the Turkish educational system, courses in life sciences, social studies and science, and, in particular, in geography provide some scope for disaster education. At university level, disaster education courses may be offered directly or indirectly in departments of primary education, science, social studies and geography, as well as in specific courses on emergency and disaster management. The aim of this study was to evaluate studies of disaster education from kindergarten to university level. To this end, the document review method, one ofthe qualitative research techniques, was used. Two doctoral theses, 27 master's theses and 29 scientific articles published between 2003 and 2020 were evaluated. These studies were foundas a result of an internet search using the keywords 'disaster' and 'disaster education' in the HEB Thesis database. The data obtained were analyzed using the content analysis method. The studies were evaluated according to the subject, method, findings and results of the research. As a result of the research, it was determined that the studies on disaster education have increased in quality and quantity in recent years. It was observed that studies have been carried out on a number of different subjects, from 'information about disasters' to'perceptions of disasters' to 'disaster behaviors', but that experimental studies were few in number. In the light of these results, recommendations are made aboutfuture disaster education.
\end{abstract}

Keywords: Disaster; Disaster education; Education levels; Research trends; Turkey

Article History: Submitted 22 August 2020; Revised 4 December 2020; Published online 13 December 2020

\section{Introduction}

Natural or human-induced disastersmay occur at any time or place. The word "disaster" comes from the Latin for "bad star", and the term itself refers to sudden and hazardous events that cause property damage, loss, and various forms of upset (Bhandari, 2014).In terms of natural or humaninduced disasters, the danger that they cause to human life and wellbeing is primary.These events and phenomena may cause loss of life, property damage, environmental destruction, and the lossofhabitable spaces. The probability of such eventsoccurring is a "risk". "Disaster risk" may be calculated in terms of thevulnerabilities that occur as a result of the daily interactions of societies and people in different social, political and environmental contexts (Gampell \& Gaillard, 2016).A

Address of Corresponding Author

Ufuk Sözcü, PhD, Kastamonu Science High School, Ministry of Education, Turkey.

$\triangle$ usozcu@hotmail.com

0000-0001-9846-5954

How to cite: Sözcü, U. (2020). Disaster education in Turkey: Trends in theses and articles between 2003 and 2020. Journal of Pedagogical Research, 4(3), 418-441. 
disaster can be defined as aneventthat causes loss of life and property, disrupts the ongoing life of societies, and may also cause a degree of environmental degradation. The UNDRR [United Nations Office for Disaster Risk Reduction] (2009), defines a disaster as "a serious disruption of the functioning of a community or society that includes widespread human, material, economic and environmental losses and impacts that exceed the capacity of the affected community or society to cope using its own resources and skills".In the literature, disasters are often classified as natural, human, technological, extraterrestrial (e.g. a meteor strike, orburst of gamma-rays or explosion from the sun) (CRED, 2018; Mata-Lima, Alvino-Borba, Pinheiro, Mata-Lima, \& Almeida, 2013; Özey, 2011; Şahin \& Sipahioğlu, 2003). In this classification, natural disasters, which can be divided into two groups, as having their origin either from the earth or from the atmosphere, are accorded most weight. According to 2018 data from CRED [Centre for Research on the Epidemiology of Disasters], 854,178 people died worldwide in natural disasters between 2000 and 2017.

There has been a considerable increase in the number of disasters in recent years. Almost every human-induced disaster experienced in the world has been due to developments in communication and transportation technologies. The AFAD [Disaster and Emergency Management Presidency] (2015), stated that this has led to an increase in the number of disasters. In addition, factors such as industrialization, the expansion of human habitation, and the attendant increase inland use have had a direct effecton the increase in loss of life and propertywhen natural disasters occur.

Disasters have always been a cause of harm to people. Yet over the years human beings have developed a number of strategiesto reduce their negative impact. The common goal of these efforts is disaster management (Coppola, 2015). Fields of study such as modern and integrated disaster management, disaster management systems, disaster awareness, disaster resilience, and disaster training and programs have been developed in order to manage disasters, and varies studies have been carried out on these issues. Contemporary disaster management seeks ways to help people cope better when disasters occur. Modern disaster management includes the stages of pre-disaster risk management (prevention and preparedness), and post-disaster crisis management (response and recovery) (Mileti, 1999). Disaster management is the entire process of analysis, planning, decision-making and evaluation that organizes existing resources for the purpose of preparedness for, mitigation of, and response to all kinds of hazards (Kadıŏlu, 2008). Disaster management thus functions as a holistic discipline. Disaster education plays a significant role in systematicallyunderstanding and thinking through these stages; it covers all stages of the modern disaster management cycle.It also includes lessons about what should be done with regard to each of the stages of pre-disaster prevention and preparedness, the moment of disaster, and postdisaster response and recovery. According to the United Nations Hyogo Framework for Action 2005-2015 (2005), the purpose of disaster education is to "create a culture of security and resilience at all levels in order to reduce the negative social and economic impacts of hazards. Disaster education aims to help people know, be aware, and prepared how they can respond before, during, and after disasters, in short, to help increase their resilience to disasters, in order to respond to disasters, and mitigate their effects (Budak, 2019; Sever, 2019; Smawfield, 2012; Ronan \& Towers, 2014, as cited in Mizrak, 2018). Disaster education can be either be carried out as 'disaster learning' within the formal education provided from kindergarten to university, or as informal education in the form of 'disaster guidance' during extra-curricular activitiesfor people of all age groups,except for those of school age (Kitagawa, 2015). In support of the latter, Shaw, Shiwaku, and Takeuchi (2011) stated that providing disaster education only through the school and university curriculum is not enough, since disaster education is mainly related to applied subjects. Shiwaku, Sakurai, and Shaw (2016) stated that the purpose of the education system should not only be to offer academic lessonsbut also to provide a safe environment for students, teachers, parents, and community members both in normal times, and when disasters occur. In this context, according to Preston (2012), disaster education, which aims to save lives and ensure the continued functioning of any society in which a disaster occurs, should be provided to citizens 
in various ways, including through brochures, public information films, television and radio broadcasts, social media, the school curriculum, family and community education, mobile phone messages, and, where applicable, early warning sirens.

After the 1999 earthquake in Izmit and Düzce, the importance of disaster management and disaster education increased in Turkey. In 2009, the Grand National Assembly of Turkey (GNAT) passed the 'Disaster and Emergency Management Law on the Organization and Functions of the Presidency' (Nr. 5902) (Meydan, 2019).The AFAD and its Disaster and Emergency Training Center (AFADEM) manage disaster education activities in Turkey. In global terms, the situation in Turkey seems to be similar to the one in Japan. After the 1995 Kobe earthquake, the Japanese government made major revisionsto its disaster management planning (Tanaka, 2012). Disaster education is an integral part of the official school curriculum in Japan. In addition, disaster education has a comprehensive public information program (Kitagawa, 2015). In the UK, disaster educationisconducted in the form of 'surge education', involving immediate curriculum responses, and public information campaigns in response to escalating threats and recent disasters. The US government has also long been providing education regarding preparedness fornatural disasters, as well as engaging the general public in national emergency and defense issues,both through formal education and widespread public information campaigns.However, there is no disaster education or national emergency preparedness program for the general public in Germany, neither in the form of the official educational curriculum, nor in the form of high-profile public information campaigns (Preston, 2008, Davis, 2007, Preston, 2010, Karutz, 2013 as cited in Chadderton, 2015).

After the Marmara earthquake in 1999, the place of disaster education in the formal education system in Turkeywas changed significantly in 2005. Maintaining an interdisciplinary approach, more units related to disaster education were included in different subjects (Shaw \& Kaneko, 2016).Disaster education studies have focused on different branches, especially in department of geography, science, and disaster management. There are gains and learning outcomes related to natural disasters in social studies and science courses at the primary school level; in science and social studies courses at the middle-school level; and in geography and biology courses at the high school level. In general, the most learning outcomes about natural disasters are found in social studies, while the fewest are found in biology. There are 13 directly related and 14 indirectly related to natural disastersin these courses, making a total of 27 . This number is clearlyinadequate given thatthe period of compulsory education is 12 years. In universities, with regard to the courses in the curriculum published by the CoHE (Council of Higher Education), onlythe courses related to disaster education inDepartments of Geography and Social Studies are mandatory, except for courses in Departments of Emergency and Disaster Management and related fields. Clearly, having individuals who have received continuous disaster education from kindergarten to university will help increase a society's ability to cope with disasters. It is thus important that disaster education is provided for all age-groups within the formal education system.Preventing disasters or surviving them with limited damage is only possible if a society and its systems are resilient (Varol \& Kırıkkaya, 2017). Individuals with insufficient disaster education will not be able to prepare for disasters effectively and will burden decision-makers during and after the disaster, thereby disruptinga society's ability to continue functioning harmoniously (Gerdan, 2019). The content and effectiveness of the training received at all education levels also need to be tested and evaluated. Zhu and Zhang (2017) examined the foreign literature on this subject in their study "Examination of Disaster Education in Primary and Secondary Schools: Evidence from China"; Johnson, Ronan, Johnston, and Peace (2014) examined disaster education programs for children in the USA; Chadderton (2015) examined disaster education in Germany; and Tanaka (2012) examined disaster policies and education in Japan. Various academic databases (CoHE Thesis, Google scholar, search engines in university e-libraries) show an increase in the number of scientific studies on disaster education in Turkey in recent years. However, there are very few studies analyzing the content of these studies. Among studies which do look at the content of 
disaster education, Değirmençay and Cin (2016) investigated earthquake education studies, while Maya and Çalışkan (2016), evaluated programs that provided disaster education at the undergraduate level in Turkey and around the world. These studies thus focused on only one subject related to disaster education. In addition, Varol (2019) examined emergency and disaster management programs in Turkey and the USA; Maya and Sarı (2017) examined disaster education issues in the curriculum of the Ministry of National Education (MoNE); Sözcü and Aydınözü (2019) examined disaster-related learning outcomes in the curricula in the context of natural disaster literacy; and Şengün and Küçülşen (2019) conducted a study on the necessity of disaster management training. These studies also evaluated the curricula and recommendations in the context of MoNE and universities. It is clear that urgent work needs to be done about disaster education in Turkey, particularly because the country is one that is constantly exposed to disasters. To do this it is first of all necessary to present a general overview of the existing studies on disaster education. This study was conducted in order to determine which groups and programs have focused on disaster education, the methods and data collection tools they have used, andthe aspects of their approaches that were adequate or inadequate, in order to provide recommendations from a holistic perspective and to thus be a guide for any future studies. The study is expected to be useful for researchers who working on disaster education and for educators and decision-makers designing disaster education programs. Ultimately, this study aimed to examine and evaluate research about disaster education in terms of its quality and quantity at all educational levels from kindergarten to university. For this purpose, articles, master's, and doctoral theses about disaster education between 2003-2020 were examined. Answers were sought to the following research questions:

- How are the studies distributed by year?

- How are they distributed by place?

- How are they distributed according to the research approach?

- How are they distributed according to the research design?

- How are they distributed according to sample characteristics?

- How are they distributed according to data collectiontools?

-What are the significant results and recommendations of the studies based on the characteristics of their samples?

\section{Method}

This section presents the research model, research scope, data collection tools, data analysis, and interpretations.

\subsection{Research Method}

In order to understand the current status of academic studies related to disaster education in Turkey, documents related to disaster education were categorizedusing specific criteria and passed through a coding process. The data were then digitized, analyzed, and interpreted to yield theoretical results from the texts. In addition, the attempt was made to determine the status of disaster education and disaster awareness in Turkey by evaluating the studies' results and the recommendations they made.Since the intended aim was tocome to anunderstanding ofthe common results of these studies, the document analysis method, which is frequently used in qualitative studies, was used for this study. While document analysis is a data collection technique when used to support other data collection tools, it can also be used as a stand-alone research method to question a situation or phenomenon (Bowen, 2009; Gross, 2018). Document analysis is the analysis of written materials that contain information about the phenomenon or facts to be investigated (Yıldırım \& Şimşek, 2013).

\subsection{Sample}

The universe of the research was all the published academic studies regarding disaster education in Turkey. The sample of the study constituted the studies on disasters and disaster education in 
all educational levels from kindergarten to university in Turkey between 2003 and 2020.The research included studies with titles and content including the words"disaster"and"disaster education" fromthe Council of Higher Education (CoHE) national thesis library, the TÜBİTAK ULAKBIM, Dergipark, EBSCOhost-ERIC databases, and the Google Scholar search engine.

In determining the studies to be included in the study, the criterion sampling method, which is one of the purposeful sampling methods, was used. The sampling criteria included: being conducted in Turkey, havinga sample from within the borders of Turkey, being related to disaster education, having a clearly stated method, and having a concern for the educational environment (textbooks, curricula, teachers, students, etc.). During the literature review, studies focusedspecifically on one type of disaster (flood, earthquake, landslide, etc.), that were not related to students or teachers, that were articles produced from a thesis, that couldbe accessed, and that did not have any educational content were excluded.Two doctoral dissertations, 27 masters'dissertations, and 29 articleswere included in the research in line with the specified criteria, for a total of 58 studies, and the information obtained from these formed the data of the study. Appendix 1 shows the studies analyzed.

\subsection{Data Collection Tools}

The Disaster Education Publication Classification Form (DEPCF) was used as a data collection tool.Studies in the literature related to content analysis and document analysis were examined (Değirmençay \& Cin, 2016; Göktaş et al., 2012; Topuz \& Göktaş, 2015), and the DEPCF was formed in line with the research problems.Peer and expert opinions were used to determine whether the prepared form coincided with the research objective. Data collected from the sample using the DEPCF in line with the research questions are presented in Table 1.

Table 1

Data collected with theDEPCF from the disaster education studies

\begin{tabular}{|c|c|}
\hline Research questions & Statement \\
\hline Working ID & $\begin{array}{l}\text { Type of study (Article, Master's thesis, Doctoral dissertation): ........ } \\
\text { Title of study: ........................ Author / Authors: ......................... } \\
\text { Publication language (Turkish / English):.............. }\end{array}$ \\
\hline Publication year & 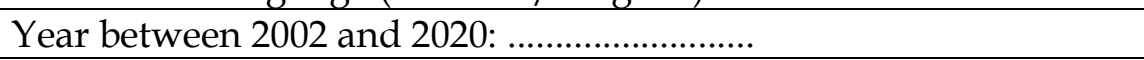 \\
\hline $\begin{array}{l}\text { Where } \\
\text { studywasconducted }\end{array}$ & City or cities where study was conducted: ................... \\
\hline Subjects of study & Topic(s) addressed: .................. \\
\hline Research approach & Research approaches used (qualitative-quantitative-mixed): ......... \\
\hline Research design & Research design used (experimental-non-experimental etc.): ....... \\
\hline $\begin{array}{l}\text { Characteristics of } \\
\text { sample }\end{array}$ & $\begin{array}{l}\text { Age and education level included (primary school, university etc.): } \\
\text {....... }\end{array}$ \\
\hline Data collection tools & Data collection tools used(survey, observation etc.): ............... \\
\hline Common results & $\begin{array}{l}\text { Most repeated results in the studies (according tocharacteristics of } \\
\text { sample): ................ }\end{array}$ \\
\hline $\begin{array}{l}\text { Common } \\
\text { recommendations }\end{array}$ & $\begin{array}{l}\text { Most repeated recommendation in the studies (according to } \\
\text { characteristics of sample): ................. }\end{array}$ \\
\hline
\end{tabular}

\subsection{Data Analysis}

As a result of the literature review, 58 studiesfound to be related to disaster and disaster education, were subjected to content analysis using the Microsoft Excel program in line with the DEPCF items. The data obtained as a result of the content analysis were analyzed using descriptive statistical methods (percentage and frequency), and then the frequency and percentages of the data answering the relevant research questions were calculated. Finally, the data were grouped, digitized, and presented in the form of tables and graphics, and the findings were interpreted. The 
content analysis method was used to answer the research question: "What are the most significant results and recommendations of the studies about disaster education based on the sample characteristics?". Content analysis determines the existence, meanings, and relationships of certain words or concepts within a text or a set of texts, and makes inferences about the message in the texts by analyzing them (Büyüköztürk, Çakmak, Akgün, Karadeniz \& Demirel, 2010). The most frequently repeated results and recommendations in the disaster education studies conducted between 2003 and 2020 were first listed according to the sampling level with DEPCF, then categorized and organized according to the research question, and finally visualized with tables to determine a theme.

\subsection{Data Analysis}

The opinions of two educational science expertswho had studied disaster education but whose work was not included in this study were consulted during the determination, analysis, and interpretation of the documents. Theconsensus of the expertswas calculated using Miles and Huberman's (1994) formula ([P (Reliability) $=[\mathrm{Na}$ (Number of Agreements) / Na (Number of Agreements) $+\mathrm{Nd}$ (Number of Disagreements)] X 100) and was found to be 0.84.In addition, the views of academic colleagues were also consulted in preparing the DEPCF.

\subsection{Role of the Researcher}

The researcher carried out the study in collaboration with experts in the field. The data collection tool was created by the researcher using various sources. The documents examined in the study were analyzed by the researcher in line with the opinions of experts and academic colleagues.

\section{Findings}

The data collected using the DEPCF were analyzed in line with research questions. The findings obtained as a result of the analysis are presented below in parallel with the research questions. Figure 1 shows the distribution of studies about disaster education by year.

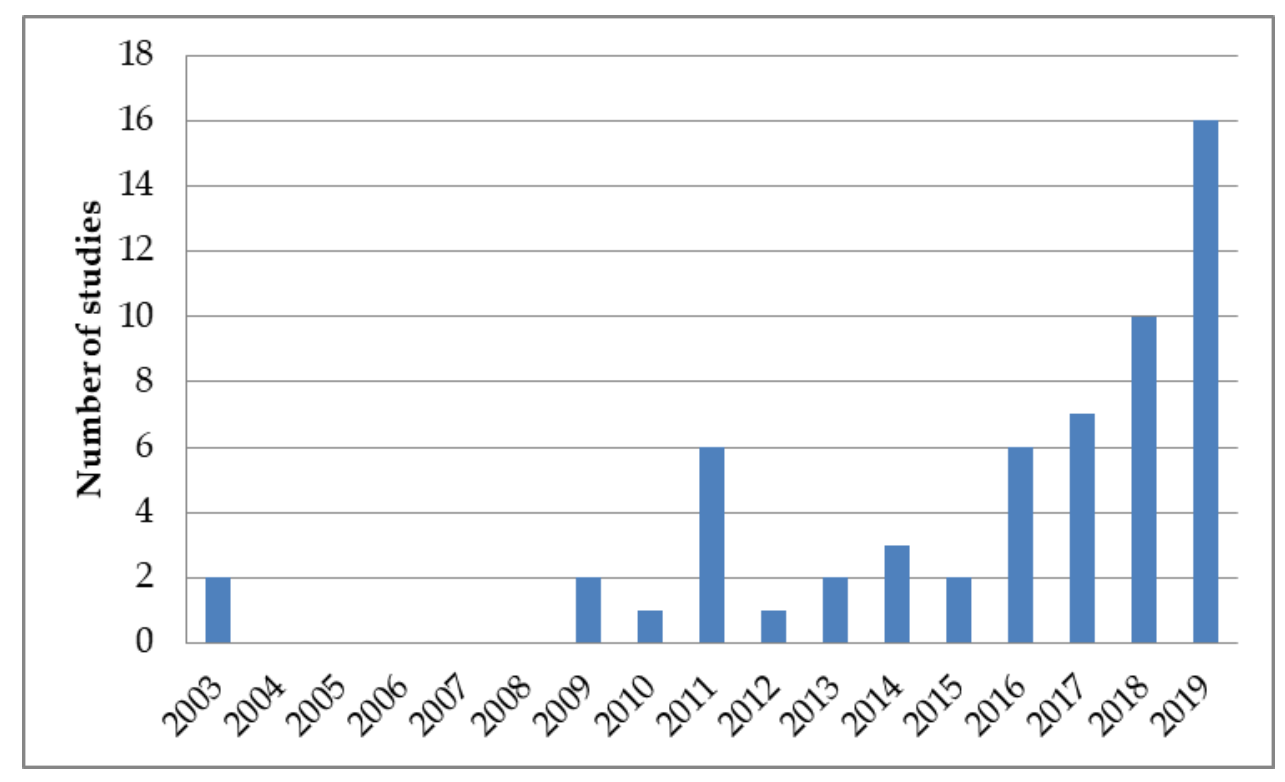

Figure 1. Distribution of disaster education studies by year

As can be seen in Figure 1, studies about disaster education have been increasingly relatively consistently over a period of 16 years. It is noteworthy that most studies were carried out in 2019: a total of 16 studies. This finding indicates that researchers' interest in disaster education has increased recently. Figure 2 shows the distribution of the cities in which disaster education studies were carried out. 


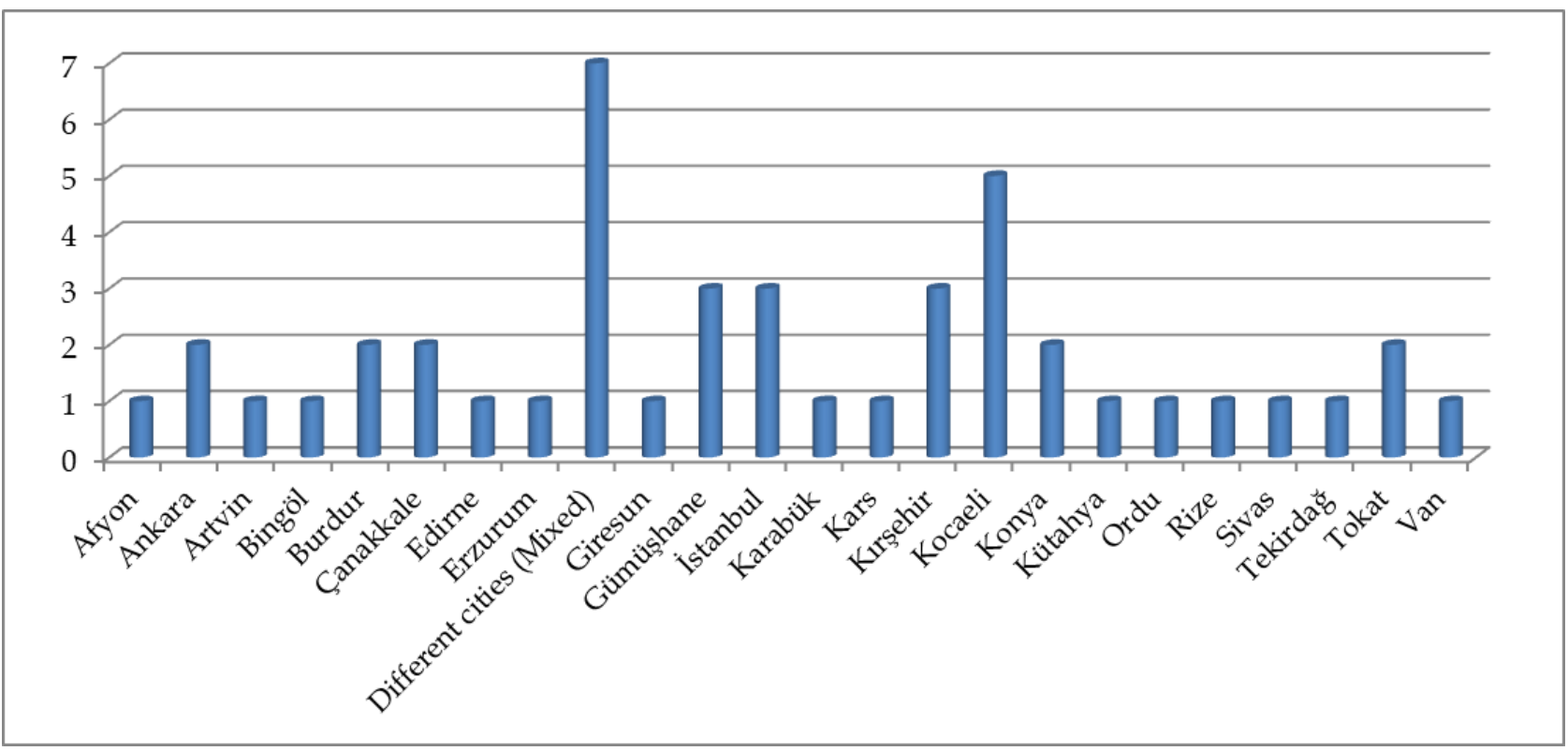

Figure 2. Distribution of cities in which disaster education studies were carried out

As can be seen in Figure 2, researchers have preferred to conduct their studies in a number cities rather than in a single city. The city most frequently studied was Kocaeli with five studies. This finding can be interpreted as demonstrating an increased focus on that region after the 1999 Izmit earthquake. Gümüşhane and Istanbul were the subjects of three studies. Seven studies focused on more than one city (Istanbul, Ankara, Erzurum, etc.). Figure 3 shows the distribution of the studies according to their subjects.

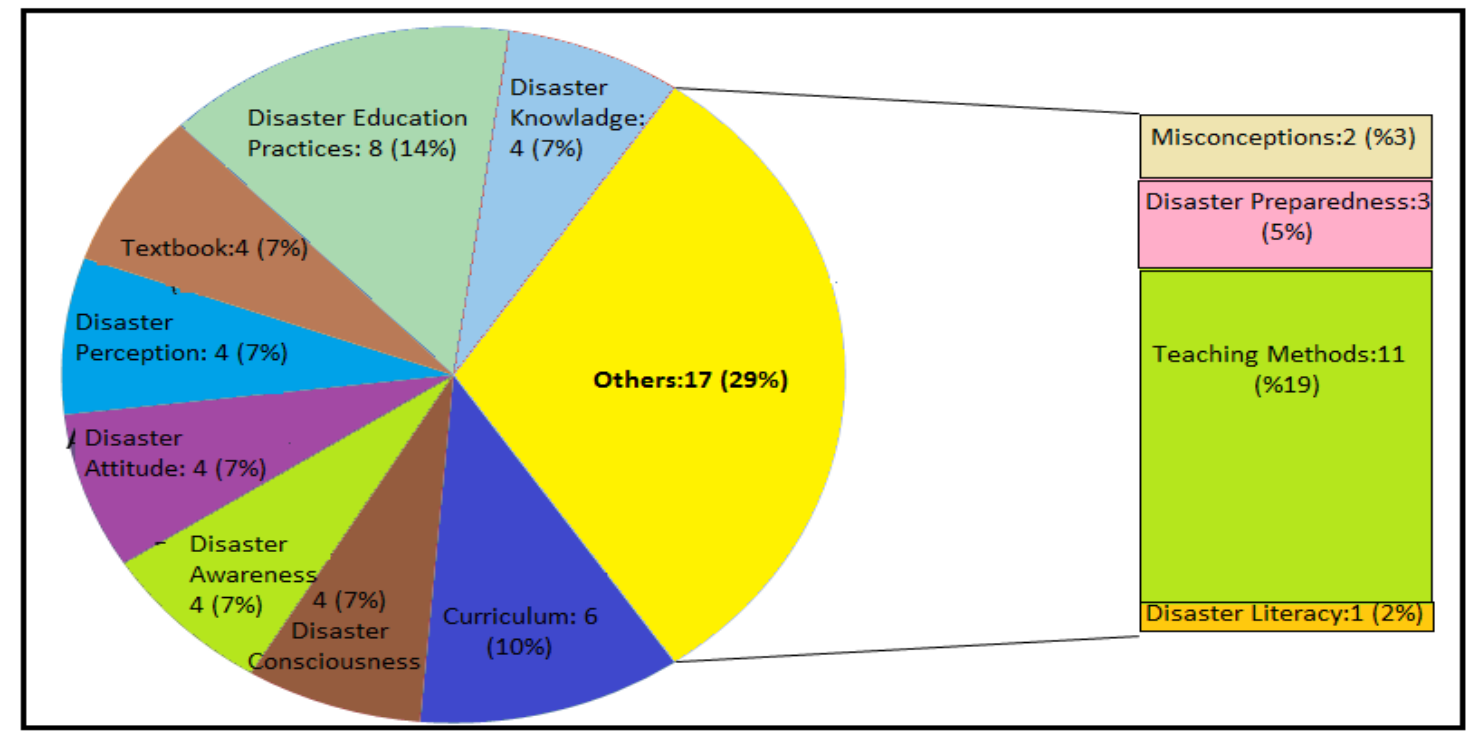

Figure 3. Distribution of disaster education studies by subject

Figure 3 shows that the studies were most concerned with teaching methods (scenario-based education, infographic education, simulation method, drama technique, etc.)These studies constituted $19 \%$ of the total studies.Apart from this, it was determined that eight studies were related to disaster education practices $(13.8 \%)$, and eight studies were related to education programs (13.8\%). In addition, there were studies on different topics, from disaster knowledge to textbooks, from misconceptions about disasters to disaster literacy.

Table 2 shows the distribution of the studies on disaster education according to the research approach. 
Table 2

Distribution of disaster education studies by research approach

\begin{tabular}{lcc}
\hline Research Approach & $\boldsymbol{N}$ & $\mathbf{\%}$ \\
\hline Qualitative & 20 & 34.5 \\
\hline Quantitative & 35 & 60.3 \\
\hline Mixed & 3 & 5.2 \\
\hline Total & 58 & 100 \\
\hline
\end{tabular}

As can be seen in Table 2, the quantitative research approach was used in 35 of the studies $(60.3 \%)$. When the types of quantitative research were examined, it was seen that the scanning model (relational scanning/descriptive scanning) was most used. It was determined that the qualitative research approach was used in 20 studies $(34.5 \%)$, and this approach was mostly chosenforresearch articles. Among the qualitative research designs, document analysis and phenomenological research designs were most frequently used.

Table 3 shows the distribution of the studies on disaster education according to the research design.

Table 3

Distribution of disaster education studies by research design

\begin{tabular}{lcc}
\hline Research Design & $\boldsymbol{N}$ & $\mathbf{\%}$ \\
\hline Experimental & 10 & 17.2 \\
\hline Non-Experimental & 48 & 82.8 \\
\hline Total & 58 & 100 \\
\hline
\end{tabular}

As can be seen in Table 3, 48 of the studies (82.8\%) had a non-experimental research design, while $10(17.2 \%)$ of the studies were conducted using an experimental research design. All of the experimental studies were dissertations or theses. Figure 4 shows the distribution of the disaster education studies by sample characteristics.

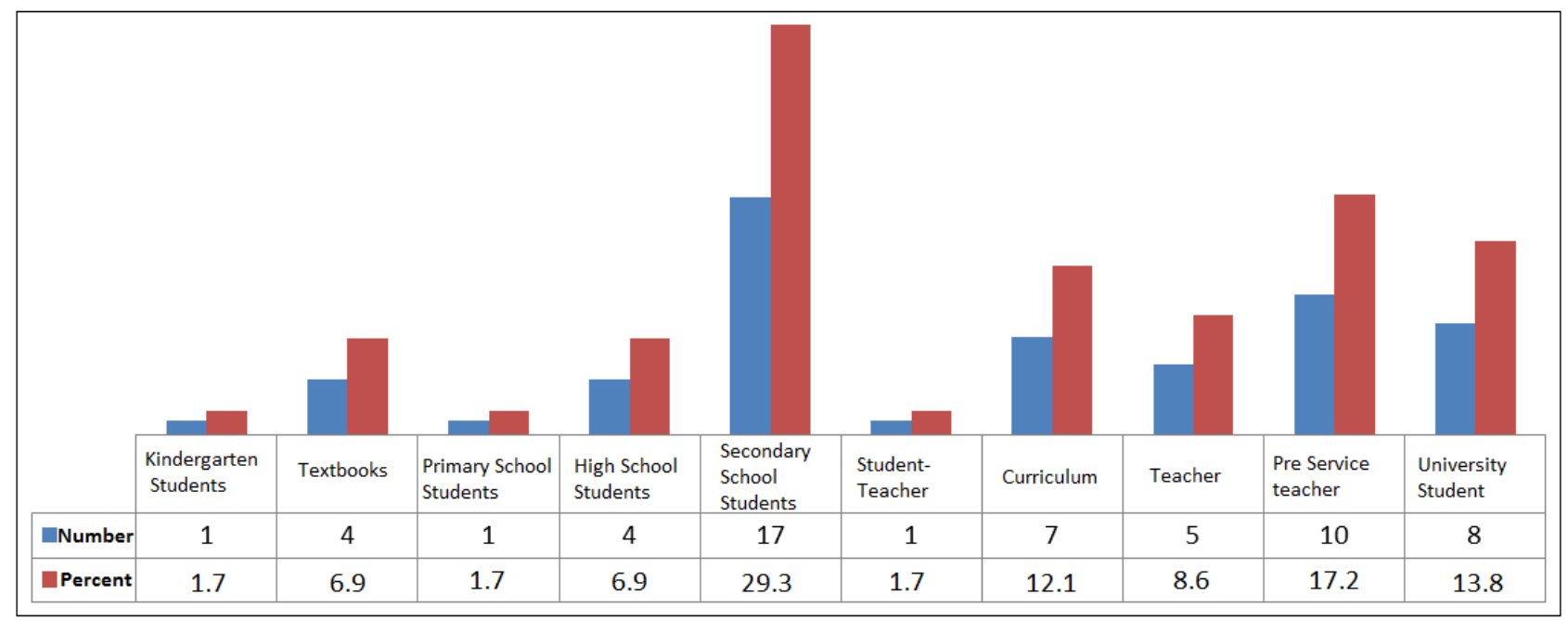

Figure 4. Distribution of disaster education studies according to sample characteristics

According to the analysis results, kindergarten students, primary-school students, middleschool students, high-school students, university students, teacher candidates, and teachers constituted the sample of the studies within the scope of the current study. Textbooks and curriculums also constituted the samples of some studies. As can be seen in Figure 4, the studies mostly focused on middle-school students. In 17 of the 55 studies examined (29.3\%), middle-school students were the sample. $10(17.2 \%)$ studies were conducted with teacher candidates, eight $(13.8 \%)$ with university students, and five $(8.6 \%)$ with teachers. In seven $(12.1 \%)$ studies the 
curriculum was selected as the sample of the study, and in four $(6.9 \%)$ studies textbooks were selected as sample. These findings indicate thatthe studies focused on specific educational levels. Figure 5 shows the distribution of the studiesaccording to whether they were theses or articles.

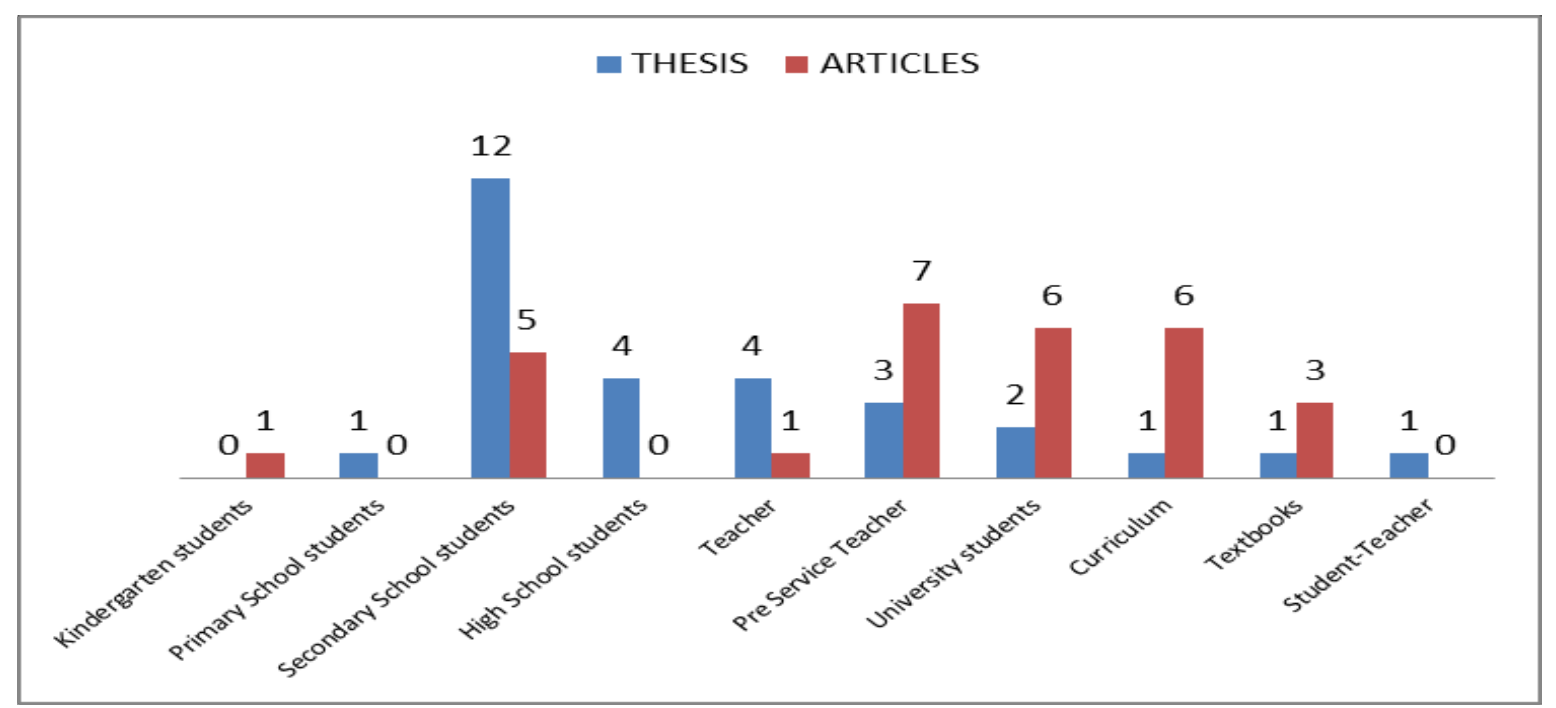

Figure 5. Distribution of disaster education studies according to their publication types

As can be seen in Figure 5, among the 29 examined theses, middle-school students constituted the sample of the study in 12 (41\%) theses. Primary-school students, curricula, and textbooks each constituted the sample of one study.Of the 29 articles examined, seven (25\%) articles focused on teacher candidates, while six (21\%) articles focused on university students and six (21\%) focusedonthe curricula. Table5 shows the distribution of the studies according to data collection tools.

Table 4

Distribution of studies by data collection tools

\begin{tabular}{lcc}
\hline Data collection tool & $N$ & $\%$ \\
\hline Questionnaire & 28 & 48.3 \\
\hline Questionnaire and Achievement Test & 3 & 5.2 \\
\hline $\begin{array}{l}\text { Questionnaire and Achievement Test and } \\
\text { Interview }\end{array}$ & 1 & 1.7 \\
\hline Questionnaire and Interview & 3 & 5.2 \\
\hline Achievement Test & 3 & 5.2 \\
\hline Document & 12 & 20.7 \\
\hline Interview & 8 & 13.8 \\
\hline Total & 58 & 100.0 \\
\hline
\end{tabular}

According to Table 4, a number of the studies used several tools for data collection. It was determined that the most common data collection tool was a questionnaire, which was used in 28 studies $(48.3 \%)$. There were also eight $(13.8 \%)$ studies in which questionnaires were used together with achievement tests and interviews. It is noteworthy that documents $(20.7 \%)$ were the second most common data collection tool and the achievement tests $(5.2 \%)$ were the least common data collection tool.

\subsection{Prominent Results and Recommendations of the Disaster Education Studies Based on Sample Characteristics}

The theme of Disaster Resilience presented in Table 5 was emerged as the most salient as a result of the content analysis of the recommendations and results of the articles, master's, and doctoral theses on disaster education completed between 2003 and 2019. Under the general heading of 
Disaster Education, the categories of Disaster Education Content, Disaster Knowledge, Attitude towards Disasters, and Sustainability of Disaster Education emerged. The studies representing the specific codes identified have beennumbered according to how they are presented in Appendix 1.

Table 5

Analysis of results and recommendations of disaster education studies

\begin{tabular}{|c|c|c|c|}
\hline Category & Code & Descriptions & $\begin{array}{l}\text { Sample Level and } \\
\text { Documents Worked on } \\
\text { (Study No.:Appendix.1) }\end{array}$ \\
\hline \multirow{3}{*}{ 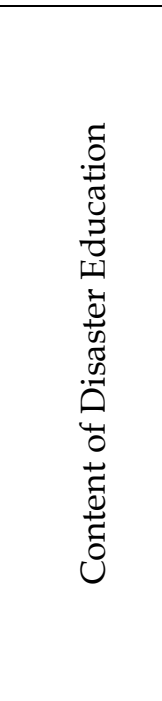 } & $\begin{array}{l}\text { Deficiencies } \\
\text { Textbooks }\end{array}$ & $\begin{array}{l}\text { Insufficient visual information about } \\
\text { disasters, incorrect and incomplete } \\
\text { information, lack of activity books on } \\
\text { disaster education, and not using different } \\
\text { methods. }\end{array}$ & $\begin{array}{l}\text { Textbooks }(9,10,23,38, \\
42,56)\end{array}$ \\
\hline & $\begin{array}{l}\text { Deficiencies in } \\
\text { theCurriculum }\end{array}$ & $\begin{array}{l}\text { Lack of holistic topics, insufficient coverage } \\
\text { of practices and activities, disaster education } \\
\text { not progressing gradually, focusing on } \\
\text { earthquakes rather than atmospheric and } \\
\text { human-induced disasters in the curriculum, } \\
\text { insufficient learning outcomes for behavior } \\
\text { and metacognitive skills. }\end{array}$ & $\begin{array}{l}\text { Curriculum } \\
\text { Middle-school students } \\
\text { Teachers(7, 14, 18,22, 24, } \\
25,31,42)\end{array}$ \\
\hline & $\begin{array}{l}\text { Good Features in } \\
\text { theCurriculum }\end{array}$ & $\begin{array}{l}\text { Common types of disasters experienced in } \\
\text { Turkey are included, the content } \\
\text { corresponds to students' cognitive level, can } \\
\text { be taughtat any level. }\end{array}$ & Curriculum(18, 24, 58) \\
\hline \multirow{3}{*}{ 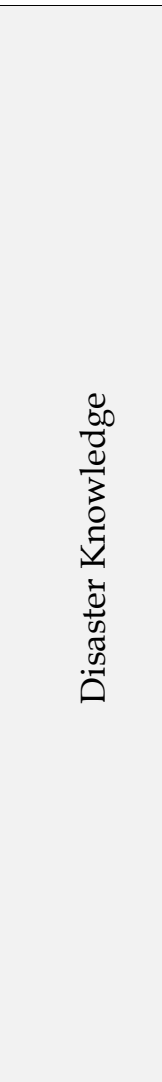 } & $\begin{array}{l}\text { Misconceptions and } \\
\text { Lack of Information }\end{array}$ & $\begin{array}{l}\text { Misconceptions and lack of knowledge } \\
\text { about disasters and disaster processes, } \\
\text { having only theoretical/memorized } \\
\text { knowledge about disasters, insufficient } \\
\text { conceptual knowledge, lack of resources for } \\
\text { disaster education. }\end{array}$ & $\begin{array}{l}\text { Middle-school students, } \\
\text { Teacher candidates, } \\
\text { Teachers }(2,7,13,16,19 \text {, } \\
20,32,48,58)\end{array}$ \\
\hline & $\begin{array}{l}\text { Knowledge } \\
\text { aboutProtecting } \\
\text { Oneself and Others } \\
\text { from Disasters }\end{array}$ & $\begin{array}{l}\text { Having knowledge and experience about } \\
\text { what to do before, during, and after } \\
\text { disasters such as earthquakes, knowing } \\
\text { aboutemergency kits, knowing emergency } \\
\text { meeting places, being familiar with disaster } \\
\text { plans, having received adequate and } \\
\text { effective disaster training, institutional } \\
\text { information, focusing ondisaster training } \\
\text { programs, participating in disaster exercises, } \\
\text { informing others about such training and } \\
\text { internalizing the training. Having or not } \\
\text { having knowledge about protection from } \\
\text { disasters. }\end{array}$ & $\begin{array}{l}\begin{array}{l}\text { Teachers, } \\
\text { students, }\end{array} \begin{array}{r}\text { Tniversity } \\
\text { Teacher }\end{array} \\
\text { candidates, } \\
\text { school students } \quad(2, \quad 5, \\
6,12,26,27,28,36,39,51 \text {, } \\
52,58)\end{array}$ \\
\hline & $\begin{array}{l}\text { Effect of Teaching } \\
\text { Methods and } \\
\text { Techniques }\end{array}$ & $\begin{array}{l}\text { The effect of different teaching methods and } \\
\text { techniques on disaster awareness and } \\
\text { teaching. }\end{array}$ & $\begin{array}{lr}\begin{array}{l}\text { Teachers, } \\
\text { students, }\end{array} & \begin{array}{r}\text { University } \\
\text { Teacher }\end{array} \\
\text { candidates, } & \text { Middle- } \\
\text { school students } & (17,30, \\
33,34,35,37,40,44,47, \\
49,53,57)\end{array}$ \\
\hline
\end{tabular}


Table 5 continued

Disaster Perception The negative associations created by the word "disaster", the level of fear and anxiety, having differentfalse beliefs, having self-confidence and the competence to cope with disasters, adopting a fatalistic, imprudent and/or insensitive approach to disasters, thinking of earthquakes as the most likely type of disaster to occur, increasing awareness in younger age groups depending on age.

Having Disaster Being sensitive to and aware of disasters Experience because of one's previous experience.

\section{Cognitive} and

Behavioral Attitudes towards Disaster

Disaster awareness: Having the necessary knowledge to protect oneself and to help others before, during, and after disasters, being able/unableto manifest these behaviors and attitudes, to have knowledge about disasters, to have incomplete information about disaster preparedness.

\begin{tabular}{|c|c|c|c|}
\hline \multirow{4}{*}{ 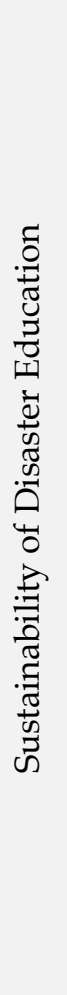 } & $\begin{array}{lr}\text { Application } & \text { of } \\
\text { Different } & \text { Teaching } \\
\text { Methods } & \text { and } \\
\text { Techniques } & \end{array}$ & $\begin{array}{l}\text { Avoiding monotony in disaster education } \\
\text { and ensuring the active participation of } \\
\text { students with different teaching methods } \\
\text { and techniques; supporting this with } \\
\text { technology, enabling the students to } \\
\text { internalize disaster awareness and behavior. }\end{array}$ & $\begin{array}{l}\text { Teacher, } \\
\text { candidates, } \\
\text { school students, Hiddle- } \\
\text { school students } \\
(15,30,33,35,37,40,41 \text {, } \\
43,44,47,49,53,57)\end{array}$ \\
\hline & $\begin{array}{l}\text { Recommendations } \\
\text { for Textbooks and } \\
\text { the Curriculum }\end{array}$ & $\begin{array}{l}\text { The introduction of disaster education at an } \\
\text { earlier age, functioning as a separate course } \\
\text { in a spiral structure at degree level, putting } \\
\text { learning related to disasters into action, } \\
\text { enriching textbooks in terms of content, } \\
\text { efficacy, and visual information, including } \\
\text { all types of disasters. }\end{array}$ & $\begin{array}{l}\text { Textbooks, Teachers, } \\
\text { Other (projects, scale } \\
\text { development, literature } \\
\text { etc.) }(2,9,22,23,25,41 \text {, } \\
42,56,58)\end{array}$ \\
\hline & $\begin{array}{l}\text { SociallyIntegrated } \\
\text { Modern } \\
\text { DisasterEducation }\end{array}$ & $\begin{array}{l}\text { Disaster education is not only limited to } \\
\text { formal education but families and the } \\
\text { communityare included in the process. }\end{array}$ & $\begin{array}{l}\text { Teachers } \\
\text { Teachers and High- } \\
\text { school students }(6,22,25 \text {, } \\
28,43,58\end{array}$ \\
\hline & $\begin{array}{l}\text { Scientific Studies } \\
\text { and the Role of the } \\
\text { Media }\end{array}$ & $\begin{array}{l}\text { Enriching the sample and applications of } \\
\text { scientific studies to disaster education and } \\
\text { communicating them to society at large, } \\
\text { ensuring that the media is active in raising } \\
\text { the public's awareness of disasterson the } \\
\text { basisof scientific knowledge. }\end{array}$ & $\begin{array}{l}\text { Teacher candidates, }(17, \\
29,34,36,57,58)\end{array}$ \\
\hline
\end{tabular}

Middle-school students, Teacher candidates, University students $(3,6$, $11,12,26,27,28,38,45$, $51,52,54)$ school students, Highschool students

$(15,30,33,35,37,40,41$

Other (projects, scale ) literature etc.) $(2,9,22,23,25,41$, $2,56,58)$
Kindergarten students, Middle-school students, Teachers, University students, Teacher candidates, Middleschool students $(1,4,6,8$, $9,13,21,46,48,51,55)$

Teacher candidates, Middle-school students, University students $(1$, $13,31,36,45,50,58)$

In the category of Disaster Education Content, the codes obtained were Deficiencies in Textbooks, Deficiencies in the Curriculum, and Good Features of the Curriculum.

The most striking results that emerged from the four studies about textbooks were that there were important problems in the visualsused in the basic educational textbooks about disasters. In terms of information, incomplete and incorrect statementswere found. In addition, different methods of how to cope with disasterswere not included in the books. It was also determined that teachers perceived the lack of activity books for disaster education as an important deficiency.

The common results of seven studies related to the curriculum under the code Deficiencies in the Curriculum can be summarized as follows: Disaster educationwas handled in a non-holistic 
way in the primary, middle, and high-school curricula; the topics coveredwere knowledge-based; the acquisitions for behavior and metacognitive skills were insufficient; disaster education did not progress gradually; there was a great deal of repetition; earthquakeswere given a lot of attention but other disasters were not adequately covered. Studies conducted at other sample levels also support these results; teachers found the learning gains indisaster education to be insufficient and incomplete.

The positive characteristics were thatthe social sciences curriculum covered the types of disasters that are most likely to occur in Turkey andthat the content was suitable for the cognitive levels of the students.However, in general, topics focusing on earthquakes were most intensively included in middle-school programs.

In the Disaster Knowledge category the following codes were obtained: Misconceptions and Lack of Information", "Knowledge aboutProtecting oneself and Others from Disasters, and Effects of Teaching Methods and Techniques.

The common results of the studies with the code Misconceptions and Lack of Informationwere as follows: Teacher candidates and middle-school students had misconceptions and a lack of knowledge about disasters. Although a significant portion of secondary-school students had some general knowledge about natural disasters, they could only provide a memorized and incomplete definition of disasters when asked. Secondary-school students did not remember human-induced disasters, and teachers had a low level of competence in providing disaster education.

One of the most important results that emerged under the Knowledge aboutProtecting Oneself and Others from Disasterswas the lack of information at all sample levels about what to do before, during, and after a disaster, and a lack of adequate participation in disaster practices. In studies with teacher samples, it was determined that teachers welcomed the training given by the AFAD, but they had insufficient knowledge about training provided by the MoNE and JICA (Japan International Cooperation Agency). In addition, the rate of participation of teacher candidates and university students in the activities of non-governmental organizations, and their level of knowledge about emergency meeting places on campus, were low. In other studiesconducted with university students, it was determined that undergraduate students had a low awareness of disaster planning, their rate of basic disaster education was very low, they did not have a disaster or emergency bag/kit, and their disaster preparedness levels were low; however, their disaster awareness level was high. It was determined that middle-school students also did not have earthquake or emergency bags/kits. It can thus beconcluded that the disaster training provided had not achieved its purpose and had not been internalized.

The effect of the teaching methods and techniques used in all the experimental and control group studies analyzed within the scope of this study was tested in teachers, teacher candidates, university students, middle-school students, and other samples. The results obtained from the experimental studies showed that active learning methods, the use of geographical information systems, drama techniques, extracurricular activities, simulation methods, infographics, disaster awareness education, scenario-based education, out-of-classroom education, and problem-based education all made a significant difference in disaster education.

In the Attitude towards Disasters category, a total of three codes were obtained: Disaster Perception, Having Disaster Experience, Cognitive and Behavioral Attitudestowards Disasters.

The results for Disaster Perception in studies conducted with middle-school students, university students, and teacher candidates demonstrated that both middle-school and university students had high levels of anxiety and fear regarding disasters. Middle-school students mostly associated the word "disaster" with the words"death" and "human", while teacher candidates associated it with "human", "exam", and "cancer". One of the common results of the studies which sampled teachers was that the teachers did not feel themselves to be competent in dealing with disasters. In addition, it was determined that teacher candidates had some partially false beliefs regarding disasters, and thatthose middle-school students who defined the concept "disaster" incompletely were indifferent to the concept. Studies in which teachers were the 
sample also concluded that the middle-school students did not take practicing for disasters seriously.Given the lack of knowledge at all sample levels, and the inadequacy of basic disaster education, it can be assumed that the society in generalmaintains a fatalistic, imprudent, and insensitive approach to potential disasters.

It was determined that at the sample levels of university students, teacher candidates, and middle-school students there was a relationship between Having Disaster Experience and being more conscious and sensitive to disasters. In these three groups, it was determined that students who had previously experienced a disaster or had lost a relative in a disaster had a higher disaster awareness and were more sensitive in developing behavior to protect themselves and others from disasters.

Under the code Cognitive and Behavioral Attitudes towards Disasters, the results of the groups consisting of teacher candidates, university students, and middle-school students stood out. While there were great deficiencies in the disaster protection behaviors of middle-school students, it was found that university students could not adequately put their knowledge about disasters into practice. It was found that teacher candidates hadnegativecognitive and behavioral attitudes towards disasters, while their affective attitudes and level of engagement indisaster education were positive.

The most repeated recommendations in the disaster education studies examined within the scope of this study were found in the Sustainability of Disaster Educationcategory, in the codes RecommendationsforTextbooks and the Curriculum, SociallyIntegrated Modern Disaster Education", Application of Different Teaching Methods and Techniques, and Scientific Studies and the Role of Media.

As a result of the positive results obtained from the experimental studies, the Application of Different Teaching Methods and Techniqueswas suggested for high-school students, teacher candidates, and middle-school students. Training that would help teachers to improve their ability to use different methods and techniques were also recommended. In addition, in studies in which teachers constituted the samples, it was recommended that teachers conduct disaster education with thesupport of technology.

The studies within the scope of this study, in parallel with the deficiencies related to the textbooks, recommended using images and graphics that would exemplify and amplify thedisaster education found in the textbooks, as well as increasing the numbers of activities and examples. In terms ofthe curriculum, the most frequently cited recommendations were as follows: in addition to the spiral teaching of the topics disasters at every grade level, compulsory or elective coursesin disaster education and disaster literacy should be available; more first-aid education should be provided at degree-level; disaster education should be compulsory in teacher education; learning gains regarding disasters should be related to behaviors.In studies conducted with teachers, the teachers stated that disaster education should begin in the pre-school period, and that disaster education should be a separate course in the curriculum.

In the Socially Integrated Modern Disaster Education code, the recommendations of the studies which samples teachers and/orhigh-school studentsfocused on plans to ensure cooperation between schools, family and the wider community with regard to disaster awareness in daily life. Providing in-service training for teachers, increasing the promotion of volunteering in community "disaster teams", and including parent training were also recommended.

Scientific Studies and the Role of the Media are important variables in the sustainability of disaster education. In studies conducted with teacher candidates, it was recommended that scientific studies on disaster education should be more widely disseminated, including through the use of different methods and techniques, and that the media should be active before potential disasters occur as well as afterwards. 


\section{Conclusion and Discussion}

This study analyzed studies focusing on disaster and disaster education from preschool to university level between 2003 and 2020. The results obtained from thecontent analysis are as follows:

When the annual distribution of the studieswas examined, it was concluded that there had been a significant increase in the number of studies carried out in the last few years. In terms of interest in disaster education in Turkey, this increase can be seen as a positive development. The spread of Emergency and Disaster Management Departments as well as the growing number of researchers in geography may have had an effect on this increase.

When the distribution of the cities where the studies were conducted was examined, it was concluded that most studies included more than one city (Ankara, Istanbul, Erzurum, Karaman, etc.). The fact that most of the single-city studies were carried out in Kocaeli can be explained by the focus on the city after the 1999 Izmit earthquake. In addition, the concentration of studies in metropolitan areas may have been due to their high populations and the inadequacy of other studies on disaster education. If a disaster occurs in any of these cities, serious problems are likely to arise. For this reason, it is important that both the public and the individuals in the municipal administrations are both disaster-literate and geographically-literate. In addition, the number of studies conducted in Gümüşhane and Çanakkale, where Emergency and Disaster Management Departments are located, was high. Although the studies were not evenly distributed locally, they were diverse. Değirmençay and Cin (2016) concluded that most earthquake-related studies were conducted in Ankara, Van, and Düzce. Although the subjects studied were similar, the cities studied were not similar. In studies related to disaster education in Turkey, earthquakes were the most studied subject. It is noteworthy that there were few studies about raising public awareness of the current situation regarding other types of disasters, such as climate-basedor technological disasters, or epidemics.

The common results and recommendations of the studies on disaster education analyzed within the scope of the research were discussed under the theme of Disaster Resilience. In the category of Disaster Education Content, the criticism was made that there were inaccuracies in terms of visuals and information provided in textbooks, and that the books did not contain any educationalactivities. However, in the last few years, the Ministry of Education has provided teachers with important resources with activity books for school-based disaster education and geography teachers. In another category, it was emphasized that topics and learning outcomes related to disasters in the curriculum were not holistic, did not progress gradually, and were earthquake-dominated. In this context, Sözcü (2020) proposed a natural disaster literacy program. Rogayan and Dollette (2020) stated that the inclusion of disaster management and disaster education in the university curriculumwould not only benefit students but also the whole society. Perdikou et al (2014) stated that disaster resistance education in higher education in Europe has increased in recent years, especially at the master's level, but has the potential for further growth.One of the positive comments about the curriculum was that it was suitable for the level of the students being taught.

In the Disaster Knowledge category, it was determined that there were various misconceptions and deficiencies in the basic knowledge regarding disasters at all educational levels. Since the foundation of being disaster-literate is one's knowledge, deficiencies in disaster knowledge in formal education are a problem. It was concluded that knowledge of how to protect oneself and others from disasters was not sufficient. When the categories were examined, another result of the research was that the studies mostly focused on teaching methods. It is promising that there have been so many studies on how to provide better disaster education to students at every education level. It is clear that using different teaching techniques and methods leads to positive results in disaster education. It has been observed that both technology-based (GIS-disaster training centers) and alternative teaching methods (drama, active learning) contribute to disaster education. It should be emphasized that many researchers have found that disaster education works best in 
places where the learning process takes place outside the traditional classroom setting. In this respect, it has been shown that experience-based and action-oriented learning have greater levels of success.Therefore, effective disaster education programs should include collaboration with researchers, local communities, and schools (Shaw, 2015; Green and Petal, 2009, as cited in Nifa, Abbas, Lin, \& Othman, 2017).

In the category of Attitudes towards Disasters, it was determined that all student groups viewed disasters in terms of "fear" and "death". Rogayan and Dollette (2020), in the study they conducted in New Zealand, also stated that the participants in their research expressed their attitudes towards disasters in a similar manner. Another result was that those who have had experience of a disaster are more sensitive and aware of them. On the other hand, Çoban, Sözbilir, and Göktaş (2017), concluded that some participants did not take any measures before a possible earthquake, although they had previously experienced one. Concerning this situation, Hoffman and Muttarak (2017) concluded that education in the Philippines and Thailand supports disasterpreparedness behaviors, especially for people who have not been affected by a disaster in the recent past. In general, it was found that students and teachers who have affectively internalized knowledge about disaster are, nevertheless, deficient in behavioral terms. As Sözcü (2019) and Sever (2020) mentioned in their studies, individuals who are fully disaster-literate should be knowledgeable, have the correct attitude, and be able to take the correct action. For this reason, it can be said that disaster education that is missing the behavioral dimensionis notsufficient. Although individuals' perceptions of disasters and their knowledge about disasters are important, how to act in the face of disastersshould be more emphasized. Zhu and Zhang (2017) stated in their study that disaster education in schools should be strengthened in order to improve students' disaster awareness and skills. In addition to all these, there is also a large number of studies on disaster perception and knowledge, so these results are in line with the research of Değirmençay and Cin (2016). However, there are few studies on pre-disaster education, disaster literacy and disaster preparedness.

In the category of Sustainability of Disaster Education, the emphasis was on the use of different teaching methods and techniques and the fact that the textbooks were satisfactory in terms of the information and visuals provided. In addition, activity-based materials, applied training in disaster training centers, as well as acting with all stakeholders in a society were found to be important for sustainable disaster education. The role of media and technology in disseminating these studies nationwide was also emphasized.

In terms of research approaches, qualitative and quantitative approaches were used in the majority ofthe studies, while the mixed approach was used in three studies. It was determined by scanning and literature review that quantitative studies use different experimental types (experimental/quasi-experimental). Johnson, Ronan, Johnston, and Peace (2014) determined that more than half of the disaster education studies in the USA were quantitative studies. The studies in Turkey and the USA are similar in this respect. Questionnaires were used as a data collection tool in approximately half of the studies considered in the sample, and data collection by interview was done in a small number of studies. More people can be reached with questionnaires, but more in-depth information can be gathered in an interview. In this respect, it can be concluded that the data collection methods varied according to the environmentin which the research was conducted, but that the data collection tools did not. In addition, it was found that most of the studies were carried out with non-experimental designs. The non-experimental studies were carried out in the form of screening, phenomenology, and case studies, and are important in terms of revealing an existing situation and establishing an infrastructure for future studies. Considering that the experimental studies consisted of studies that test a teaching method, it can be said that they do provide examples for future studies. However, Johnson et al. (2014) stated that while prior studies have provided valuable information, there is very limited empirical evidence about how disaster education programs facilitate children's roles in preparing their families for disasters, their ability to protect themselves, or how disaster-prepared they will be as adults. 
Middle-school students were most frequently studied. It is important to assess middle-school students because education received at younger ages is more valuable.However, that the studies focused on university students at approximately the same rate as middle-school students and gave little space to pre-school and primary school students wasa deficiency. In addition, it wasbeneficial that the number of studies focusing on the curricula and textbooks was high. In this way, deficiencies in courses and textbooks were detected andrecommendations were made to correct them. Similarly, Johnson et al. (2014) determined that disaster education studies in the USA were mostly aimed at students in the 7-13 age-group. Also, there were more studies aimed at teachersin the USA than in Turkey. The results of the research are generally in parallel with those of Değirmençay and Cin (2016). When the studies were examined according to their types, it was concluded that the theses focused mostly on middle-school students, while the articles focused on university students and teacher candidates.

Disaster education studies worldwidedifferent by country.It has been pointed out that it is difficult to handle disaster education officially in Germany since it has 16 different official curricula throughout the country, and teachers there have relatively autonomy (Chadderton, 2015). Nurdin (2019) also points out that teachers in Indonesia do not have enough knowledge about disaster risk reduction, and moreover, lack of creativity and enthusiasm to enable progress in schools. Disaster education studies in schools have gained momentum in Japan since the early 2000s. It has been stated that by making safety education compulsory, it has become necessary for teachers to provide guidance in physical education, local studies, and extra-curricular activities in primary schools, and to cooperate with the school, family, and local community for support (Kitagawa, 2015). France, on the other hand, has its own disaster education system consisting of four specific goals. The first goal is to help children prepare for and protect themselves from the risks they may face in their daily lives. The second is toinform students about the various emergency resources available in their communities and to provide contact information for each.The third goal is a short survival and safety course. Finally, the fourth goal is to help students become more responsible, both as individuals and as a group (United Nations Office for Disaster Risk Reduction, 2007). In the USA, training courses such as Savior Friends, Disaster Masters, Disney's Pillowcase Project, and Stop Disasters were organized for the disaster education of young people (Kendall, 2016). Perdikou et al. (2014) found that multidisciplinary disaster resistance education in higher education in Europe has increased rapidly in recent years, although it is still not sufficient. Rogayan and Dollette (2020), in their study in New Zealand, found that the public lacked disaster knowledge and that the public and students should be taught geography. As can be seen, various different typesof disaster education studies have been conducted in countries with different levels of disaster education.

\section{Recommendations}

In light of the results of the current research, further recommendations for disaster education studies and for improving the quality of disaster education in Turkey are given below:

As Fuhrmann et al. (2008) stated in their studies, we do notknow how or in what form we will encounter a disaster in the future. For this reason, we should educate people, especially our students, on how to prepare for, react to, and deal with disasters; in short, we need to become a disaster-resilient society. This education should be integrated with both social sciences (geography, history, economics, etc.) and health and science studies. As Park (2020) states, the human and social features of disasters should be taught in conjunction with their scientific and technological aspects and a link should be established between the two. Giventhat learning that occurs at younger ages is more permanent, more studies should be conducted aboutdisaster education forstudents in kindergarten and primary school to eliminate any deficiencies.

Almost every region in Turkey experiences different types of disasters. For this reason, it would be beneficial for future studies to focus more on specific regions throughout the country. 
Finally, with regard to the deficienciesfound in the studies examined here, it is recommended that future studies be conducted with an emphasis on experimental methods, and that more qualitative studies be conducted.

The following recommendations are put forward based on the results of the studies examined within the scope of this research:

Since it can be difficult to correct mistaken learning that may occur as a result of mistakes in basic education books, it would be beneficial if thosesections of textbooks that focus on disasters were prepared by experts in disaster and disaster education.

Since there were no samplesfocusing on different relationshipssuch as teacher/student, teacher/student/parent, teacher candidate/lecturer, local people/university student in the current studies, focusing on these in future studies may contribute to disaster education.

In order to contribute to applied disaster education, excursions could be planned, particularly for primary school students, in order to enable them to learn from simulators and technological equipment in AFEM (Disaster Education) centers. In addition, it is important to increase the materials related to disaster education available through the EIN (Education Information Network), which has become an important element of education in recent years.

Since having experience a disaster increases disaster awareness, students could visitspecific regions after a disaster has occurred.Education about risk management rather than crisis management should also be increased. In this respect, activities related to investigating potential sources of danger in their homes could be designed for students. These would contribute to students' first-hand knowledge and awareness of future dangers. Given the current prevalence of social media, sharing disaster education content on these platforms in a planned manner, at regular intervals, and in a way that will keep it visible and relevant, should also be encouraged.

\section{References}

Note. “*” References marked with an asterisk indicate studies included in the review. The in-text citations to studies selected for the review are not followed by asterisks.

*Adanal1, R. (2018). The effect of problem based learning supported by geocaching game on teaching natural disasters (Doctoral dissertation). Obtained from the Higher Education Council National Thesis Center. (Thesis no.524524)

AFAD (2015). Preparation of integrated hazard maps, landslide-rock fall basic guide. Retrieved from https://www.afad.gov.tr on March 30, 2020.

*Akçil, Ö. (2011). Development and exploring the effectiveness of the revised version of basic disaster awareness training program designed in a non-formal science learning environment. Unpublished Master Thesis, Boğaziçi University, Graduate Program in Secondary School Science and Mathematics Education, İstanbul.

*Arslan, E. (2016). Evaluation of information, attitudes and behaviors of Trakya University Faculty of Medicine students about disaster-emergency situations. Unpublished Master's Thesis. Trakya University, Edirne.

${ }^{*}$ Avc1, K. (2019). The views of student, teacher $\mathcal{E}$ disaster trainer related to disaster education $\mathcal{E}$ the technology used in the disaster education (a sample of Bursa Disaster Education and Simulation Center)Unpublished Master's Thesis. Gazi University, Ankara.

Bhandari, R. K. (2013). Disaster education and management: A joyride for students, teachers and disaster managers. Springer Science \& Business Media.

Budak, F. (2019). Disasters and disaster management. In R.Sever (Ed.), Disaster education (p.184-192), Ankara: Pegem Academy.

*Bozyiğit, R., \& Kaya, B. (2017). Determining the cognitive structures of geography pre-service teachers on some concepts related to the natural disasters. Marmara Geographical Journal, 35, 55-67.

Bowen, G. A. (2009). Document analysis as a qualitative research method. Qualitative Research Journal, 9(2), 27-40. http://www.doi.org/10.3316/QRJ0902027

Büyüköztürk, Ş., Çakmak, K. E., Akgün, Ö. E., Karadeniz, Ş., \& Demirel, F. (2014). Scientific research methods (18th Edition). Ankara: Pegem Academy. 
Chadderton, C. (2015). Civil defence pedagogies and narratives of democracy: disaster education in Germany. International Journal of Lifelong Education, 34(5), 589-606.

${ }^{*}$ Cin, M. (2010). Prospective Classroom Teachers' Misconceptions About Natural Hazards. Marmara Geographical Journal, 22, 70-81.

Coppola, D. P. (2015). Introduction to international disaster management. Butterworth-Heinemann.

*Coşkun, Ş. (2011). Disaster education perception: a study to measure perception of disaster education provided to primary school students. Unpublished Master Thesis. Sakarya University, Sakarya.

CRED.(2018). Economic losses, poverty Edısasters. Retrieved from https://www.cred.be/\#pager on December $17,2019$.

*Çakır, U. (2017). The effects of scenario based training on disaster related information and attitude levels of secondary school students. Unpublished Master Thesis, Gazi University Institute of Educational Sciences, Ankara.

Çoban, M., Sözbilir, M., \& Göktaş, Y. (2017). Determining preparation perceptions before earthquake of individuals experienced earthquake: a case study. Eastern Geography Journal, 22(37), 113-134.

Değirmençay, Ş. A.. \& Cin, M. (2016). Earthquake education researches in Turkey: a descriptive content analysis. Yüzüncü Yal University Journal of Education, 13(1), 301-314.

*Değirmenci, Y. \& İlter, İ. (2013). The natural disasters in the geography teaching curriculum. Marmara Geographical Journal, 28, 276-303.

*Değirmenci, Y., Kuzey, M. \& Yetişensoy, O. (2019). Disaster awareness and education in social studies textbooks. E-Kafkas Journal of Educational Research, 6(2), 33-46.

*Dikmenli, Y., \& Gafa, İ. (2017). Perception of disaster at different educational stages. Mehmet Akif Ersoy University Journal of Education Faculty, 44, 21-36.

${ }^{*}$ Dikmenli, Y., Yakar, H., \& Konca, A. S. (2018). Development of disaster awareness scale: A validity and reliability study. Review of International Geographical Education Online, 8(2), 206-220.

*Dikmenli, Y.\& Yakar, H. (2019). Examining of preservice teachers' disaster awareness levels. YüzüncüYıl University Journal of Education, 16(1), 385-416.

*Doğru, D. (2019). The effect of teaching natural disasters with infographics in secondary school geography lessons on student achievement and course attitude. Unpublished Master's Thesis. Cumhuriyet University, Sivas.

*Dökmeci, A. H. \& Merinç, F. (2018). The evaluation of disaster awareness of Namık Kemal University students. Disaster and Risk Magazine, 1(2), 106-113.

*Duman-Kocabaş, N. (2011). How can natural disasters be studied in the history textbooks of secondary education in Turkey? ( A Model Recommendation ). Unpublished Master's Thesis. GaziUniversity, Ankara.

*Durna, H. (2009). Teaching the subject of natural disasters with active learning method in 10th grade geography lesson and its effect on student success. Unpublished Master's Thesis, Marmara University, İstanbul.

*Erdur-Baker, Ö., Kasapoğlu, K., \& Yılmaz, E. (2015). The objectives of disaster education from teachers' perspectives. International Journal of Human Sciences, 12(1), 975-990.

*Erdoğan, H. (2009). Teaching natural disasters subject in secondary education geography lessons using geography information system implementation (arcgis). Unpublished Master's Thesis. Marmara University, İstanbul.

Fuhrmann, S., Stone, L. D., Casey, M. C., Curtis, M. D., Doyle, A. L., Earle, B. D., ...\& Schermerhorn, S. M. (2008). Teaching disaster preparedness in geographic education. Journal of Geography, 107(3), 112-120.

Gampell, A. V., \& Gaillard, J. C. (2016). Stop disasters 2.0: Video games as tools for disaster risk reduction. International Journal of Mass Emergencies and Disaster, 34(2), 283-316.

*Gençoğlu, S. E. (2019). Investigetion the 6th grade students perceptions about natural disaster trough the word association tests. Unpublished Master Thesis. NiğdeUniversity,Niğde.

*Gerdan, S. (2014). Determination of disaster awareness, attitude levels and individual priorities at Kocaeli University, Eurasian Journal of Educational Research, 55, 159-176. http://dx.doi.org/4689/ejer.2014.55.10

Gerdan, S. (2019). Disaster trainings as a social responsibility field. International Journal of Management and Administration, 3(5), 101-110.

Göktaş, Y., Küçük, S., Aydemir, M., Telli, E., Arpacık, Ö., Yıldırım, G. \& Reisoğlu, İ. (2012). Educational technology research trends in Turkey: a content analysis of the 2000-2009 decade. Educational Sciences in Theory and Practice, 12(1),177-199.

Gross, J.M.S. (2018). Document analysis. In Frey, B.B.(Ed.), The SAGE encyclopedia of educational research, measurement, and evaluation ( pp. 544-548). Thousand Oaks, California: Sage Publications.

Hoffmann, R., \& Muttarak, R. (2017). Learn from the past, prepare for the future: Impacts of education and experience on disaster preparedness in the Philippines and Thailand. World Development, 96, 32-51.

*Irkıçatal, G. (2014). Impacts of natural disasters on paintings drawn by 5th grade students (Van Province Earthquake Case).Unpublished Master's Thesis. Gazi University, Ankara. 
*Inal, E., Kaya, E., \& Altıntaş, K. H. (2018). Evaluating the formal education in terms of sufficiency of disaster education in turkey. Atatürk University Journal of KazımKarabekir Education Faculty, 37, 114-127.

Johnson, V. A., Ronan, K. R., Johnston, D. M., \& Peace, R. (2014). Evaluations of disaster education programs for children: A methodological review. International journalJof Disaster Risk Reduction, 9, 107-123.

Kadıoğlu, M. (2008). Principles of modern integrated disaster management system. Basic Principles of Disaster Risk Reduction, JICA Turkish Office Publication, 2, 1-34.

*Kara, İ. (2018). The disaster awareness of secondary school 8th grade students: sample of Niksar, Erbaa, Taşova Provinces. Unpublished Master's Thesis, 18 Mart University Institute of Educational Sciences, Çanakkale.

*Karakuş, U. \& Önger, S. (2017). The understanding levels on natural disasters and disasters education concepts for 8th grade students students. Journal of History Culture and Art Research, 6(6), 482-491. http://dx.doi.org/10.7596/taksad.v6i6.1247

*Karataş, O. (2011). The effect of drama technique to the success of students in education of natural disaster in social studies course a first stage of primary school (experimental study). Unpublished Master's Thesis, Kafkas University, Kars.

*Kaymak, F. (2003). 6th grade primary school students' level of understanding of concepts related to natural disasters and their misconceptions. Unpublished Master's Thesis, Karadeniz Technical University Institute of Social Sciences, Trabzon.

Kendall, B. (2016). Teaching preparedness to better prepare children in the event of disaster (Order No. 10117123). Available from ProQuest Dissertations \& Theses Global. (1803936532). Retrieved from https:// search.proquest.com/docview/1803936532?accountid=107421

${ }^{*}$ Kılıç, B. C. (2019). Evaluation of natural disasters topic on life science and social studies course books in terms of spiral system. Unpublished Master's Thesis, BalıkesirUniversity, Balıkesir.

*Kırıkkaya, E. B., \& Gerdan, S. (2018). Opinions of disabled and disabled candidate individuals about how they behave at a disaster. Resilience, 2(2), 123-129.

*Kırıkkaya, E. B., Ünver, A. O., \& Çakın, O. (2011). Teachers views on the topic of disaster education at the field on elementary science and technology curriculum. Necatibey Faculty of Education Electronic Journal of Science and Mathematics Education, 5(1), 24-42.

*Kırıkkaya, E. B., \& Gerdan, S. (2018). Opinions of disabled and disabled candidate individuals about how they behave at a disaster. Resilience, 2(2), 123-129.

*Kısa, G. (2019). Activity recommendations about natural disasters matching with 2018 social studies curriculum.Unpublished Master's Thesis, Balıkesir University, Balıkesir.

Kitagawa, K. (2015). Continuity and change in disaster education in Japan. History of education, 44(3), 371-390.

*Kortak, V. (2019). The attitudes of social studies education students related to disaster. Unpublished Master's Thesis, Onsekiz Mart University Institute of Educational Sciences, Çanakkale.

*Köçer, M.S.(2019). Relationship between attitudes towards disaster with environmental sensitivity of university students. Unpublished Master's Thesis, Onsekiz Mart University Institute of Educational Sciences, Çanakkale.

Mata-Lima, H., Alvino-Borba, A., Pinheiro, A., Mata-Lima, A., \& Almeida, J. A. (2013). Impacts of natural disasters on environmental and socio-economic systems: what makes the difference? AmbienteESociedade, 16(3), 45-64.

Maya, I., \& Sar1, B. (2017). The evaluation of the issues in disaster training and disaster education curriculum Ministry of Education in Turkey. IX. International Educational Research Congress

Maya, I.,\& Çalışkan, C. (2016). Evaluating disaster education and training programs at the level of undergraduate degree in The World And Turkey Sample. Electronic Turkish Studies, 11(9).

Meydan, A. (2019). Disasters and disaster management. In R.Sever (Ed.), Disaster management (pp. 216-231), Ankara: Pegem Academy.

Mızrak, S. (2018). Education, disaster education and the resilient society. MuğlaSıtkıKoçman University Journal of Education Faculty, 5(1), 56-67.

Miles, M. B. \& Huberman, A. M. (1994). An expanded sourcebook qualitative data analysis. Thousand Oaks, California: Sage Publications.

Mileti, D. (1999). Disasters by Design : A reassessment of natural hazards in the United States, Joseph Henry Press.

Nifa, F. A. A., Abbas, S. R., Lin, C. K., \& Othman, S. N. (2017). Developing a disaster education program for community safety and resilience: The preliminary phase. AIP Conference Proceedings, 1891(1), 020005.

Nurdin, N. (2019). Disaster risk reduction in education and the secondary high school science curriculum in Indonesia (Order No. 27788442). Available from ProQuest Dissertations \& Theses Global.(2340365117). Retrieved from https:/ / search.proquest.com/docview /2340365117?accountid=107421 on June 1, 2020. 
*Oral, V. (2018). Evaluation of the institutional preparations of the primary schools for disaster and emergency situations (Gümüşhane Province Sample). Unpublished Master's Thesis, Gümüşhane University, Gümüşhane.

*Öcal, A., Yildirim, E., Yakar, H., \& Erdoğan, E. (2016). Examination of social studies prospective teachers' beliefs on disasters. Kirıkkale University Journal of Social Sciences, 6(2), 59-72.

*Öcal, A. Çakır, U., \& Özelmacı, Ş. (2016). Disaster preparedness and safety living in primary and secondary school curriculums. Journal of Field Education Research, 2(2), 71-83.

*Önal, H. (2019). Shortcomings in disaster concepts in basic education textbooks. Turkey Social Research Journal, 23(1, 177-192).

*Özelmac1, Ş. (2016). A study on the perceptions of secondary school students on disasters and disaster preparedness. Unpublished Master's Thesis, Gazi University Institute of Educational Sciences,Ankara.

Özey, R. (2011). Geography of disasters, Second Edition, Istanbul: Aktif publishing house.

*Özkazanc, S., \& Yüksel, U. D. (2015). Evaluation of disaster awareness and sensitivity level of higher education students. Procedia-Social and Behavioral Sciences, 197, 745-753.

*Özmen, B., \& İnce, Z. D. (2017). School-Based disaster education. Resilience, 1(1), 21-29.

*Özgen, N., Ünaldı, Ü. E., \& Bindak, R. (2011). Determining the teacher candidates' "effective learning styles" on natural disasters. Journal of Ahi Evran University Kirşehir Faculty of Education, 12(4), 303-323.

Park, W. (2020). Beyond the 'two cultures' in the teaching of disaster: or how disaster education and science education could benefit each other. Educational Philosophy and Theory, 52(13), 1-15.

Perdikou, S., Horak, J., Palliyaguru, R., Halounová, L., Lees, A., Ranguelov, B., \& Lombardi, M. (2014, January). The current landscape of disaster resilience education in Europe. In R. Haigh, D. Amaratunga, K. Keraminiyage and M. Thayaparan (Eds.), Proceedings of the 4th International Conference on Building Resilience, Incorporating the 3rd Annual Conference of the ANDROID Disaster Resilience Network 2014 (pp. 568-575). Elsevier.

*Pinar, A. (2017). What is secondary school students' awareness on disasters? a case study, Review of International Geographical Education Online (RIGEO), 7(3), 315-331.

*Piyadeoğlu Kaya, O. (2019). The effect of disaster awareness education on secondary school students' knowledge levels: Gümüşhane Province sample. Unpublished Master's Thesis, Gümüşhane University, Gümüşhane.

Preston, J. (2012). Disaster education: 'Race', equity and pedagogy. Berlin: Springer.

Rogayan, D. V. Jr., \& Dollete, L. F. (2020). Disaster awareness and preparedness of Barrio community in Zambales, Philippines: creating a baseline for curricular integration and extension program. Review of International Geographical Education, 10(2), 92-114.

*Sapsağlam, Ö. (2019). Natural disaster awareness in preschool children. Ondokuz Mayis University Journal of Education, 38(1), 283-295.

*Sarı, B. (2016). The evaluation of disaster education implementation in terms of teachers' opinion in Turkey. Unpublished Master Thesis, 18 Mart University Institute of Educational Sciences, Çanakkale.

Sever, R. (2019). Disasters and disaster management. In R.Sever (Ed.), Basic Concepts (pp. 2-11), Ankara: Pegem Academy.

Shaw, T., \& Kaneko, F. (2016). International cooperation: interventions in enhancing disaster education in Turkey. In Disaster Resilience of Education Systems (pp. 195-211).Springer, Tokyo.

Shaw, R., Shiwaku, K., \& Takeuchi, Y. (Eds.). (2011). Disaster education. Emerald Group Publishing.

Shiwaku, K., Sakurai, A. \& Shaw, R. (2016). Disaster Resilience of Education Systems. Disaster Risk Reduction.Springer, Tokyo.

Smawfield, D. (Ed.). (2012). Education and natural disasters. Bloomsbury Publishing

*Sözcü, U. (2019). Determining natural disaster literacy levels of preservice teachers. Unpublished PhD Thesis, Kastamonu University Institute of Social Sciences, Kastamonu.

Sözcü, U. (2019). Natural disasters and natural disaster literacy (2nd edition), Ankara: Pegem Academy.

Sözcü, U. (2020). Natural disaster literacy curriculum proposal. Disaster and Risk Journal, 3(1), 70-79.

*Sözcü, U. \& Aydınözü, D. (2019). Study of disaster-related acqusitions in curriculum in terms of natural disaster literacy. Turkish Studies Educational Sciences, 14(5), 2639-2652.

*Şahan, C. (2019). Examination on the effect of disaster and earthquake education given by using simulation method on secondary school students in disaster education center. Unpublished Master Thesis. 18 Mart University, Çanakkale.

*Şahin, Y., Lamba, M., \& Öztop, S. (2018). Determination of disaster awareness and preparedness level of university students. Journal of Civilization Studies, 3(6), 149-159.

Şahin, C. \& Sipahioğlu, Ş. (2003). Natural disasters and Turkey (2nd edition). Ankara: Training and Publishing. 
Şengün, H. \& Küçükşen, M..(2019). Why is the disaster management training required? Erciyes University Journal of Social Sciences Institute, 33(46), 193-211.

Tanaka, Y. (2012). Disaster policy and education changes over 15 years in Japan. Journal of Comparative Policy Analysis: Research and Practice, 14(3), 245-253.

*Taş, G. (2003). Natural disasters in secondary education institutions in turkey (earthquakes, mass movements, volcano, frost event) evaluation of the teaching of the subject. Unpublished Master Thesis. Gazi University Institute of Educational Sciences, Ankara.

Topuz, A. C. \& Göktaş, Y. (2015). Projects for the effective use of technology in the Turkish education system: period of 1984-2013 . International Journal of Informatics Technologies, 8(2), 99-110.

*Turan, M., Doğan, G., Bulut, Y., Öztürk, G., \& Şahinöz, S. (2018). Higher education society preparedness to emergencies and disasters activities and responsibilities in Gümüşhane University. Gümüşhane University Journal of Health Sciences, 7(1), 1-11.

*Turan, İ. \& Kartal, A. (2012). Misconceptions of the fifth grade students on natural disasters. Ahi Evran University Kırşehir Journal of Faculty of Education, 13(3).

*Türkan, A. H., \& Kılıç, İ. (2017). A description on cognitive, affective and behavioral dimensions of attitudes of university students towards disasters. Itobiad: Journal of the Human \& Social Science Researches, 6(1 114127).

United Nations (2005). Hyogo Framework for Action 2005-2015: Building the resilience of nations and communities to disasters. Retrieved from http:// www.refworld.org/docid/42b98a704.html on August 27, 2019.

United Nations Office for Disaster Risk Reduction. (2007). Towards a culture of prevention: Disaster risk reduction begins at school. Retrieved from www.unisdr.org/files/761_educationgood-practices.pdf on May 23, 2019.

United Nations Office for Disaster Risk Reduction. (2009). Terminology on disaster risk reduction. Retrieved from https:/ / www.unisdr.org/files/7817_UNISDRTerminologyEnglish.pdf on May 23, 2019.

*Ursavaş, M. (2016). The observation of views and the consciousness level of students towards natural disasters which take place in secondary school social studies curriculum (the example of Burdur City). Unpublished Master Thesis. Mehmet Akif Ersoy University, Burdur.

*Uzunyol (2013). Investigation of the knowledge levels of 8th grade students on natural disasters according to various variables. Unpublished Master Thesis. Niğde University Institute of Educational Sciences, Niğde.

Varol, A . (2019). Disaster management, disaster education and awareness in disaster management: American Example. Firat University Journal of Social Sciences, 29(1), 193-204.

Varol, N., \& Kırıkkaya, E. B. (2017). Community Resilience against disasters. Journal of Resilience, 1(1), 1-9.

*Yazıcı, Ö., \& Ulu Kalın, Ö. (2018). A comparative analysis of conceptual metaphors for "natural disaster". EKafkas Journal of Educational Research, 5(1), 25-40.

Yıldırım, A. \& Şimşek, H. (2013). Nitel araştırma yöntemleri [Qualitative research methods]. Ankara: Seçkin Publications.

*Ylmaz, E. (2014). School-based disaster education through curricular and extra-curricular activities: a comparative case study. Unpublished Master's Thesis, Middle East Technical University, Ankara.

Zhu, T. T. \& Zhang, Y. J. (2017). An investigation of disaster education in elementary and secondary schools: evidence from China. Natural Hazards, 89(3), 1009-1029. 
Appendix 1. Studies analyzed within the scope of the research

\begin{tabular}{|c|c|c|}
\hline \multicolumn{3}{|c|}{ ANALYZED ARTICLES } \\
\hline $\begin{array}{l}\text { Study } \\
\text { No. }\end{array}$ & The name of the study & Authors- Year \\
\hline 1 & Examining of Preservice Teachers' Disaster Awareness Levels & Dikmenli \& Yakar (2019) \\
\hline 2 & $\begin{array}{l}\text { Teachers Views on the Topic of Disaster Education at the Field on } \\
\text { Elementary Science And Technology Curriculum }\end{array}$ & $\begin{array}{l}\text { Kırıkkaya, Ünver \& } \\
\text { Çakın (2011) }\end{array}$ \\
\hline 3 & $\begin{array}{l}\text { Determination of Disaster Awareness And Preparedness Level of } \\
\text { University Students }\end{array}$ & $\begin{array}{l}\text { Şahin, Lamba \& Öztop } \\
(2018)\end{array}$ \\
\hline 4 & Natural Disaster Awareness in Preschool Children & Sapsağlam (2019) \\
\hline 5 & $\begin{array}{l}\text { on of Disaster Awareness, Attitude Levels and Individual } \\
\text { Kocaeli University }\end{array}$ & Ger \\
\hline 6 & $\begin{array}{l}\text { A Description on Cognitive, Affective and Behavioral Dimensions of } \\
\text { Attitudes of University Students Towards Disasters }\end{array}$ & \& Kilıç (2017) \\
\hline 7 & Perception of Disaster at Different Educational Stages & Dikmenli \& Gafa (2017) \\
\hline 8 & $\begin{array}{l}\text { A Comparative Analysis of Conceptual Metaphors for "Natural } \\
\text { Disaster" }\end{array}$ & Yazıcı \& Ulu Kalın (2018) \\
\hline 9 & Disaster Awareness and Education in Social Studies Textbooks & $\begin{array}{l}\text { ci, Kuzey \& } \\
\text { y (2019) }\end{array}$ \\
\hline 10 & ation & \& İnce (2017) \\
\hline 11 & $\begin{array}{l}\text { Opinions of Disabled and Disabled Candidate Individuals About } \\
\text { How They Behave at a Disaster }\end{array}$ & $\begin{array}{l}\text { Kırikkaya \& Gerdan } \\
(2018)\end{array}$ \\
\hline 12 & $\begin{array}{l}\text { The Evaluation of Disaster Awareness of Namik Kemal University } \\
\text { Students }\end{array}$ & $\begin{array}{l}\text { Dökmeci \& Merinç } \\
(2018)\end{array}$ \\
\hline 13 & $\begin{array}{l}\text { The Understanding Levels on Natural Disasters and Disasters } \\
\text { Education Concepts for 8th Grade Students Students }\end{array}$ & Karakuş \& Önger (2017) \\
\hline 14 & $\begin{array}{l}\text { Disaster Preparedness and Safety Living in Primary and Secondary } \\
\text { School Curriculums }\end{array}$ & $\begin{array}{l}\text { Öcal, Çakır \& Özelmac1 } \\
\text { (2016) }\end{array}$ \\
\hline 15 & es of Disaster Education From Teachers' Perspectives & $\begin{array}{l}\text {-Baker, Kasapoğlu } \\
\text { maz (2015) }\end{array}$ \\
\hline 16 & Students On Natural Disasters & \& \& Kartal (2012) \\
\hline 17 & $\begin{array}{l}\text { g The Teacher Candidates' “Effective Learning Styles” On } \\
\text { asters }\end{array}$ & $\begin{array}{l}\text { Özgen, Ünaldı \& Bindak } \\
\text { (2012) }\end{array}$ \\
\hline 18 & sters in The Geography Teaching Curriculum & Değirmenci \& İlter (2013) \\
\hline 19 & $\begin{array}{l}\text { Determining the Cognitive Structures of Geography Pre-Service } \\
\text { Teachers On Some Concepts Related To The Natural Disasters }\end{array}$ & Bozyiğit \& Kaya (2017) \\
\hline 20 & $\begin{array}{l}\text { Prospective Classroom Teachers' Misconceptions About Natural } \\
\text { Hazards }\end{array}$ & Cin \\
\hline 21 & $\begin{array}{l}\text { Examination of Social Studies Prospective Teachers' Beliefs On } \\
\text { Disasters }\end{array}$ & $\begin{array}{l}\text { Öcal, Yıldırım, Yakar \& } \\
\text { Erdoğan (2016) }\end{array}$ \\
\hline 22 & $\begin{array}{l}\text { Evaluating the Formal Education In Terms of Sufficiency of Disaster } \\
\text { Education In Turkey }\end{array}$ & $\begin{array}{l}\text { İnal, Kaya \& Altıntaş } \\
(2018)\end{array}$ \\
\hline 23 & Shortcomings in Disaster Concepts in Basic Education Textbooks & Önal (2018) \\
\hline 24 & $\begin{array}{l}\text { Study of Disaster-Related Acqusitions In Curriculum In Terms of } \\
\text { Natural Disaster Literacy }\end{array}$ & $\begin{array}{l}\text { Sözcü } \quad \& \\
(2019)\end{array}$ \\
\hline 25 & bility Field & Gerdan (2019) \\
\hline 26 & $\begin{array}{l}\text { dness to Emergencies and Disasters } \\
\text { ümüşhane University }\end{array}$ & $\begin{array}{l}\text { Turan, Doğan, Bulut, } \\
\text { Öztürk \& Şahinöz (20189 }\end{array}$ \\
\hline 27 & $\begin{array}{l}\text { Evaluation of Disaster Awareness and Sensitivity Level of Higher } \\
\text { Education Students }\end{array}$ & $\begin{array}{l}\text { Özkazanç \& Yüksel } \\
\text { (2015) }\end{array}$ \\
\hline 28 & $\begin{array}{l}\text { What is Secondary School Students' Awareness on Disasters? A Case } \\
\text { Study }\end{array}$ & Pinar (2017) \\
\hline 29 & $\begin{array}{l}\text { Development of Disaster Awareness Scale: A Validity And Reliability } \\
\text { Study }\end{array}$ & $\begin{array}{l}\text { Dikmenli, Yakar } \\
\text { Konca (2018) }\end{array}$ \\
\hline
\end{tabular}


Appendix 1 continued

\section{ANALYZED MASTER'S RESEARCH}

30 Teaching the Subject of Natural Disasters with Active Learning Method in 10th Grade Geography Lesson and its Effect on Student Success

$31 \quad$ Natural Disasters in Secondary Education Institutions in Turkey (Earthquakes, mass movements, Volcano, Frost Event) Evaluation of the Teaching of the Subject

32 6th Grade Primary School Students' Level of Understanding of Concepts Related to Natural Disasters and Their Misconceptions

33 Teaching Natural Disasters Subject in Secondary Education Geography Lessons Using Geography Information System İmplementation (Arcgis)

34 Disaster Education Perception: A Study to Measure Perception of Disaster Education Provided to Primary School Students

35 The Effect of Drama Technique to The Success of Students In Education of Natural Disaster In Social Studies Course A First Stage of Primary School (Experimental Study)

36 Investigation of the Knowledge Levels of 8th Grade Students on Natural Disasters According to Various Variables

37 School-Based Disaster Education Through Curricular And ExtraCurricular Activities: A Comparative Case Study

38 The Observation of Views and the Consciousness Level of Students Towards Natural Disasters Which Take Place in Secondary School Social Studies Curriculum (The Example of Burdur City)

39 The Evaluation of Disaster Education Implementation in Terms of Teachers' Opinion İn Turkey

40 Examination on The Effect of Disaster And Earthquake Education Given By Using Simulation Method On Secondary School Students in Disaster Education Center

\begin{tabular}{clc}
\hline 41 & $\begin{array}{l}\text { Activity Recommendations About Natural Disasters Matching With } \\
\text { 2018 Social Studies Curriculum }\end{array}$ & Kisa (2019) \\
\hline 42 & $\begin{array}{l}\text { Evaluation of Natural Disasters Topic on Life Science and Social } \\
\text { Studies Course Books in Terms of Spiral System }\end{array}$ & Kilıç (2019) \\
\hline 43 & $\begin{array}{l}\text { The Views of Student, Teacher \& Disaster Trainer Related To Disaster } \\
\text { Education \& The Technology Used in the Disaster Education (A } \\
\text { Sample of Bursa Disaster Education and Simulation Center) }\end{array}$ & Doğru (2019) \\
\hline 44 & $\begin{array}{l}\text { The Effect of Teaching Natural Disasters with Infographics in } \\
\text { Secondary School Geography Lessons on Student Achievement and } \\
\text { Course Attitude }\end{array}$ & Kortak (2019) \\
\hline 45 & The Attitudes of Social Studies Education Students Related to Disaster \\
\hline 46 & $\begin{array}{l}\text { A Study on the Perceptions of Secondary School Students on Disasters } \\
\text { And Disaster Preparedness }\end{array}$ & Özelmac1 (2016) \\
\hline 47 & $\begin{array}{l}\text { Development and Exploring the Effectiveness of the Revised Version } \\
\text { of Basic Disaster Awareness Training Program Designed in A Non- } \\
\text { Formal Science Learning Environment }\end{array}$ & Akçil (2011) \\
\hline 48 & $\begin{array}{l}\text { Investigetion the 6th Grade Students Perceptions About Natural } \\
\text { Disaster Trough the Word Association Tests }\end{array}$ & Gençoğlu (2019) \\
\hline 49 & $\begin{array}{l}\text { The Effect of Disaster Awareness Education On Secondary School } \\
\text { Students' Knowledge Levels: Gümüşhane Province Sample }\end{array}$ & Kaya (2019) \\
\hline 50 & $\begin{array}{l}\text { Relationship Between Attitudes Towards Disaster With } \\
\text { Environmental Sensitivity of University Students }\end{array}$ & Köçer (2019) \\
\hline 51 & $\begin{array}{l}\text { The Disaster Awareness of Secondary School 8th Grade Students: } \\
\text { Sample of Niksar, Erbaa, Taşova Provinces }\end{array}$ & Kara (2018) \\
\hline
\end{tabular}

Durna (2009)

Taş (2003)

Kaymak (2003)

Erdoğan (2009)

Coşkun (2011)

Karataş (2011)

Uzunyol (2013)

Yllmaz (2014)

Ursavaş (2016)

Sar1 (2016)

Şahan (2019)

Kisa (2019)

Kılıç (2019)

Avc1 (2019)

Education \& The Technology Used in the Disaster Education (A

Sample of Bursa Disaster Education and Simulation Center)

Secondary School Geography Lessons on Student Achievement and Course Attitude

A Study on the Perceptions of Secondary School Students on Disasters

Özelmacı (2016)

Akçil (2011) of Basic Disaster Awareness Training Program Designed in A NonInvestigetion the 6th Grade Students Perceptions About Natural The Effect of Disaster Awareness Education On Secondary School Student' Knowledge Levels: Gumuşhane Province Sample Relationship Between Attitudes Towards Disaster With The Disaster Awareness of Secondary School 8th Grade Students: Sample of Niksar, Erbaa, Taşova Provinces 
Appendix 1 continued

52 Evaluation of The Institutional Preparations of The Primary Schools For Disaster And Emergency Situations (Gümüşhane Province Sample)

53 The Effects of Scenario Based Training On Disaster Related Information and Attitude Levels of Secondary School Students

Oral (2017)

Evaluation of Information, Attitudes and Behaviors of Trakya

Çakır (2017)

University Faculty of Medicine Students about Disaster-Emergency Situations

55 Impacts of Natural Disasters on Paintings Drawn By 5th Grade Students (Van Province - Earthquake Case)

56 How Can Natural Disasters be Studied in the History Textbooks of Secondary Education in Turkey? (A Model Recommendation )

Arslan (2016) DOCTORAL STUDIES ANALYZED

57 The Effect of Problem Based Learning Supported By Geocaching Game On Teaching Natural Disasters

58 Determining Natural Disaster Literacy Levels of Preservice Teachers 